
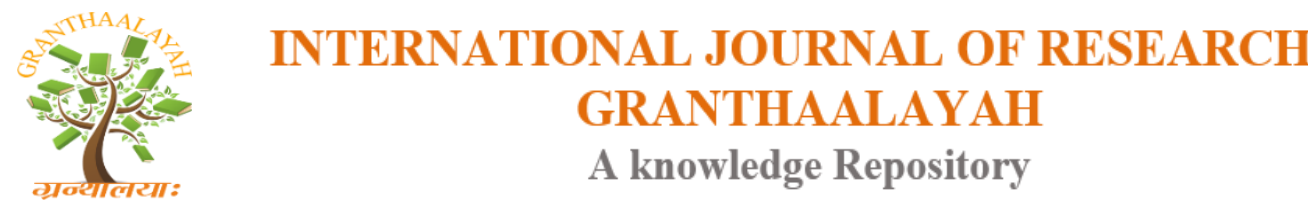

Management

\title{
CUSTOMER EXPERIENCE MANAGEMENT IN BANKING SECTOR - A BRIEF REVIEW
}

\author{
M.B. Suvarchala ${ }^{* 1}$, Prof.V. Narasimha Rao *2 \\ ${ }^{* 1}$ M.B.A., M.Phil., Ph.D. Scholar, Acharya Nagarjuna University, Nagarjuna Nagar, Guntur Dt., \\ A.P., India \\ ${ }^{* 2}$ M.Com., M.B.A., Ph.D, Director: KBN College P.G. Centre, Research Guide, Acharya \\ Nagarjuna, Krishna \& JNTU-K Universities, Vijayawada, Krishna Dt., A.P., India
}

\begin{abstract}
The competition among the organizations in financial services sector is continuously increasing. Banking industry is a backbone of nation's economy and it is one of the largest industries in India in terms of revenue and employment. The banking structure played a major role in the mobilisation of savings and promoting economic development. The intensity of customer-organisation relationship has changed dramatically over time. Customer experience is the product of an interaction between an organisation and a customer over the duration of their relationship. The key elements like strategy, culture, processes and systems etc. impact the CEM in banks. The antecedents like customer knowledge management, satisfaction, trust and loyalty influence the CEM in organizations. This paper is an attempt to trace out the elements of CEM and the various factors leading to the neglect of CEM in banking sector.
\end{abstract}

Keywords: Antecedents; Retail Banking; Customer Expectations; Social Environment; Service Encounter; Service Offering; Electronic Channels.

Cite This Article: M.B. Suvarchala and Prof.V. Narasimha Rao. (2018). "CUSTOMER EXPERIENCE MANAGEMENT IN BANKING SECTOR- A BRIEF REVIEW.” International Journal of Research - Granthaalayah, 6(7), 164-178. 10.29121/granthaalayah.v6.i7.2018.1295.

\section{Introduction}

The financial services industry (of which retail banking forms an integral part) is continuing its dynamic change. Dibb and Meadows (2001:169) argue that the major players in retail banking are becoming increasingly blurred as the effects of mergers, flotations and new market entrants are felt. More than ever before, retail banking managers needs a detailed understanding of their customers, their current and potential profitability, how to meet the needs of their best customers successfully by providing an appropriate range of financial services, and how to prevent these valuable customers from switching to other service providers. All of this must be done while keeping costs down and ensuring that business processes are streamlined and efficient. 
Retail banks are reshaping the business tactically and strategically to achieve stiff balance sheet and income statement goals. It is interesting to observe that these goals are achieved through traditional branch banking sales and service, focusing on existing customers (70-75\% of sales) and setting behavioural standards for banking staff (Anat, 2006:1-2).

However, there is a change in the air for retail banking. Retail banks all see the competition increasing across the media, mail and physical changes in branches. Retail banks see new forms and new names selling financial products. A retail bank has to have confidence in its strategies, the simplicity of its actions and speed in its implementation of change (Croxford, et al., 2006:15).

Retail banks differentiate themselves by the effectiveness of their strategic decisions. Fundamental differentiators are more powerful than tactical differentiators that have become more difficult to create and more difficult for competitors to compete against (Croxford et al., 2006:83). According to Croxford et al. (2006:84), "service and customer experiences are important differentiators" in retail banking. "The customer experience is a combination of everything you do, or fail to do for that matter, that underpins any interaction with a customer or potential customer" (Shaw, 2005:5).

\section{Customer Experience Management}

Customer Experience is the product of an interaction between an organization and a customer over the duration of their relationship. This interaction is made up of three parts: the customer journey, the brand touch points the customer interacts with, and the environments the customer experiences (including digital environment) during their experience. A good customer experience means that the individual's experience during all points of contact matches the individual's expectations.

Customer experience implies customer involvement at different levels - such as rational, emotional, sensorial, physical, and spiritual. Customers respond diversely to direct and indirect contact with a company. Direct contact usually occurs when the purchase or use is initiated by the customer. Indirect contact often involves advertising, news reports, unplanned encounters with sales representatives, word-of-mouth recommendations or criticisms.

Customer experience encompasses every aspect of a company's offering - the quality of customer care, of course, but also advertising, packaging, product and service features, ease of use, and reliability. Creating direct relationships in the place where customers buy, use and receive services by a business intended for customers such as in-store or face to face contact with the customer which could be seen through interacting with the customer through the retail staff. We then have indirect relationships which can take the form of unexpected interactions through a company's product representative, certain services or brands and positive recommendations - or it could even take the form of "criticism, advertising, news, reports' and many more along that line. Customer experience is created by the contribution of not only the customers' values but also by the contribution of the company providing the experience.

Wharton's Professor of Marketing Barbara E. Kahn has established an evolutional approach to customer experience as the third of four stages of any company in terms of its customer centricity maturity. These progressive phases are: 
1) Product orientation: Companies just manufacture goods and offer them the best way possible.

2) Market orientation: Some consideration on customer needs and segmentation arises, developing different marketing mix bundles for each one.

3) Customer experience: Adding to the other two factors some recognition of the importance of providing an emotionally positive experience to customers.

4) Authenticity: This is the top maturity stage of companies. Products and service emerge from real soul of brand and connect naturally and on long term sustainable basis with clients and other stakeholders.

Kotler et al. 2013, say that customer experience is about, "Adding value for customers buying products and services through customer participation and connection, by managing all aspects of the encounter". The encounter includes touch points. Businesses can create and modify touch points so that they are suited to their consumers' which changes/enhances the customers' experience. Creating an experience for the customer can lead to greater brand loyalty and brand recognition in the form of logos, colour, smell, touch, taste, etc.

According to Bernd Schmitt, "the term 'Customer Experience Management' represents the discipline, methodology and/or process used to comprehensively manage a customer's crosschannel exposure, interaction and transaction with a company, product, brand or service." Adam Richardson says that a company must define and understand all dimensions of the customer experience in order to have long-Term success.

The aim of CEM is to optimize the customer experience through gaining the loyalty of the current customers in a multi-channel environment and ensure they are completely satisfied. Its also to create advocates of their current customers with potential customers as a word of mouth form of marketing.

\section{Review of Literature}

Rangarajan C (2007) in his lecture focuses on the banking sector reforms and improvement in the performance of Indian banking Industry. It is held that the development of the financial system is essential for sustaining higher economic growth. Reform measures were initiated in India so that banks can overcome external constraints and operate with greater flexibility. Favourable impact of banking sector reforms on Indian banking Industry is also shown. Proper attention should be paid to issues like consolidation, capital adequacy, risk management and customer service. Productivity and Profitability can be improved by combining corporate planning with organisational restructuring. Financial inclusion and governance have emerged as the key issues for socio-economic development.

Verma Amitabh (2009) evaluated the impact of technology on the performance of Indian banks in terms of their profitability and productivity. IT has become buzzword in Indian banking industry. Technology can be the key differentiator between two banks and major actor to attain competitive edge. The primary challenge for banks is to provide consistent service to customers irrespective of the kind of channel they use. It was concluded that Indian Public sector banks have a unique 
advantage over their counterparts in terms of their branch network and the large customer base but it is the use of technology that will enable Public Sector Banks to build on their strengths.

Schmitt (1999) says that companies can create experiential marketing by having customers sense, feel, think, act and relate to a company and its brands. The experience concept has also redefined branding to more than just logos, slogans, awareness and image. The brand is about creating and delivering a specific targeted experience associated around a product or service.

Gerald Zaltman (2003) propose that sub-conscious sensory and emotional elements derived from the total experience has a strong influence on the customer preference than the tangibles of a service. Almost ninety five percent of the processing of the experience at touch points during interactions takes place at the unconscious level. He claims that the perception of experience happens at the subconscious level. Customers consciously \& unconsciously filter a barrage of clues and organize them into a set of impressions. Some are rational and some are emotional.

Stephan H. Haeckel, Lewis P. Carbone, and Leonard L. Berry (2003) revealed that Customer experience management focuses different parts of an organization on the common goal of creating an integrated and aligned customer feeling. It provides a means for breaking down organizational barriers. They had identified three principles that would result in a distinctive customer value through customer experience. The three principles are as below:

Principle 1: Fuse experiential breadth and depth

Principle 2: Use Mechanics and Humanics to improve function

Principle 3: Connect Emotionally. Connecting emotionally with customer or managing customer emotions are not easily understood.

Dikesh Kumar (2009) propose that Customer Experience is a way to meet and exceed the expectation of end customer through all channels of interaction. This leads to increased advocacy and referrals for the bank and ultimately profitable revenue growth. The customer continues to expect outstanding service, customized product, anytime-anywhere access to their money and realtime update and alerts of transaction across all channels. The benefits of a holistic, end-to-end approach to customer service results by managing customer relationships with real-time information and by providing excellent customer experiences leading to lifetime loyalty from the customer. But, managing customer experience across channels is not an easy job. It requires an organization wide activity to bridge the various channels. Only then the customer interaction across channels can be managed to result in an overall customer experience.

\section{Objective of the Study}

The Present study has been carried out to highlight the importance of customer experience management in banks. The study mainly attempts to identify and explain the elements of CEM and the factors behind neglecting of CEM in retail Banking. 


\section{Data Sources and Methodology}

The study was of descriptive nature and relies on secondary data sources. The information, conceptual base was extracted from existing research papers, Annual Reports of banks and other relevant publications on the banking sector.

\section{Elements of CEM in Banks}

From the definitions of customer experience management given above it is clear that the customer experience management consists of a variety of elements. The following key elements of customer experience management are entrenched across the organisation (Shaw, 2005: xix), namely strategy, culture, customer expectations, processes, channel approach, marketing and brand, systems, people and measurement.

Strategy: The first important element of a total customer experience is strategy. Organisations require a strategy that creates a unified view of customers from the perspectives of operations, analytics and collaboration along the entire customer relationship value chain (Heskett, 1997:106).

Culture: The second important element of a total customer experience is culture. Culture refers to the shared values, vision or credo that creates a propensity for individuals to act in certain ways. According to Hrebiniak (2005:261) organisational culture includes the norms and values of the organisation, including the vision shared by its personnel. Culture usually has a behavioural component, defining the "way an organisation does things".

Customer expectations: The third important element of a total customer experience is customer expectations. The expectations of customers serve as a benchmark in terms of which present and future service encounters can be compared. Customer expectations are what customers think they will receive from a service encounter. These expectations may be divided into at least three levels.

1) The predicted service level (the anticipated level of performance).

2) The desired service level (the level of service the customer wants or hopes to receive compared to the predicted service level).

3) The adequate service level (the minimum level of service the customer will tolerate or accept without being dissatisfied) (Cant, et al., 2002:239).

Parasuraman, et al. (1990:34) state that customers evaluate an organisation's service quality by comparing service performance (perceptions) with what they think performance should be (expectations). Customers' service expectations provide a context for their assessment of the service. When service performance falls short of expectations a service quality gap results as depicted in the figure given below.

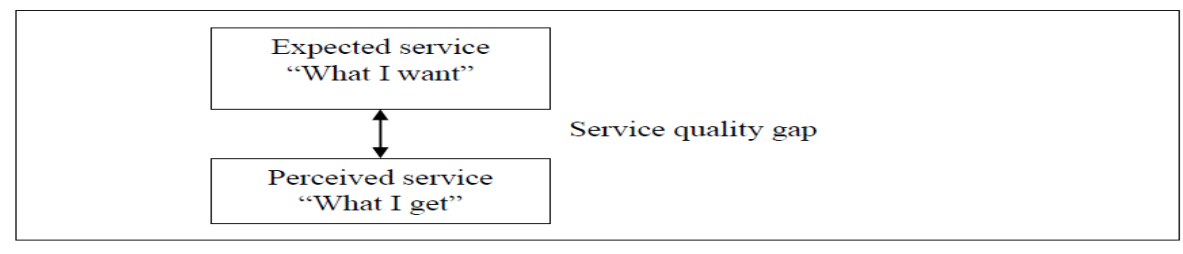

Figure 1: Service Quality Gap 
A number of different attributes contribute to understanding customer expectations and customer loyalty, namely people, product and service delivery, place (convenience), product features, price, policies and procedures, and promotion and advertising (Smith, 2001:5). Two primary components exist in this context, namely physical and relational. Physical context is referred to as "mechanics clues" (sights, smells, sounds and textures). Relational context is referred to as "humanic clues" (people behaviours). Managing customer experience means "orchestrating" all these "clues" to meet or exceed people's emotional needs and expectations. A successful service experience provider such as Disney spends many months on training employees in relational methods for them to connect emotionally with guests during social interactions (Pullman \& Gross, 2003:218).

Processes: The fourth important element of a total customer experience is process. According to the Oxford dictionary, a process is "a series of actions or tasks performed in order to do, make or achieve something" (Hornby, 1998:922). Process has been identified as one of the additional elements to the marketing mix. Once organisations have a shared view of customer experience, processes are needed to reinforce and support the goal of improving customer experience (Dorsey \& Bodine, 2006:7).

Marketing and brand: The sixth important element of a total customer experience is marketing and the brand. Marketing is defined as "a social process by which individuals and groups obtain what they need and want through creating and exchanging products and value with others" (Kotler, 1984:4). More recently, Hair, Bush and Ortinau (2006:5) state that marketing's purpose is to enable an organisation to plan and implement "pricing, promotion and distribution or products, services and ideas to create satisfaction.

According to Aaker and Keller (1990:29) an important brand association is the overall brand attitude. Brand attitude is based on certain attributes such as durability, incidence of defects, serviceability, features and performance. Attitude is conceptualised in terms of the customer's perception of the overall quality of the brand.

An organisation's first step in managing total customer experience is recognising the clues it is sending to customers. The clues that make up a customer experience are everywhere and easily discerned. Anything that can be perceived or sensed - or recognised by its absence - is an experience clue. Thus the product or service provides one set of clues, the physical setting offers more clues, and the employees - through their gestures, comments, dress and tone of voice provide still more clues (Berry, Carbone \& Haeckel, 2002:85-86).

"A strong brand promise can influence what customers remember about their experiences with a product or service" (Barlow \& Steward, 2004:42). Barlow and Steward (2004:45) also believe that a brand idea can be enforced by means of pictures, language and behaviour - all of which evoke emotions. Human behaviour is the primary means of brand reinforcement within the realm of customer service.

"Branding should be the differentiating mechanism, separating an organisation "s products and services from those of its competitors" (Kumar, 2004:148). It is the brand that shapes customer experience. Customers come to a brand with a set of assumptions about that brand. The brand and the customer experience should correspond (Shaw 2005:137). 
Systems: The seventh element of a total customer experience is systems. Systems are designed and managed in organisations through information technology (IT). IT enables modern organisations to integrate their supply, production and delivery processes so that operations are triggered by customer orders, not by production plans that push products and services through the value chain. An integrated system, from customer orders upstream to raw material suppliers, enables all the organisational units along the value chain to realise enormous improvements in cost, quality and response time (Kaplan \& Norton, 1996:4).

People: People are the eighth important element of a total customer experience. People are one of the 7Ps of the marketing mix, also referred to as personnel or employees, represent the "key battleground for many organizations" (Ind, 2001:67-72). An organisation in Stockholm (Ind, 2001:67-72) defined 4Fs to steer its employees: fun, fame, fortune and future. The 4Fs were designed to influence how people behaved internally and how they interacted with customers.

\section{Why CEM Neglected}

CEOs may not actively deny the significance of customer experience or, for that matter, the tools used to collect, quantify, and analyze it, but many don't adequately appreciate what those tools can reveal. Three forces in the main conspire to preserve this gap.

\section{Too Much Money Already Lavished on CRM}

Having spent millions of dollars on customer relationship management software, many CEOs consider their problem to be not a lack of customer information but a superfluity of it. Before investing more time and money, executives justifiably want to know how customer experience data are different and what their value is.

To put it starkly, the difference is that CRM captures what a company knows about a particular customer-his or her history of service requests, product returns, and inquiries, among other things - whereas customer experience data capture customers' subjective thoughts about a particular company. The CRM tracks customer actions after the fact; CEM (customer experience management) captures the immediate response of the customer to its encounters with the company. Employees accustomed to reading the marketing department's dry analyses of CRM point-of-sale data easily grasp the distinction upon hearing a frustrated customer's very words. (For a detailed account of the difference between the two approaches, see the exhibit-1 "CEM Versus CRM.")

Exhibit 1: CEM Vs CRM

\begin{tabular}{|l|l|l|l|l|l|}
\hline & \multicolumn{1}{|c|}{ What } & \multicolumn{1}{|c|}{ When } & $\begin{array}{c}\text { How } \\
\text { Monitored }\end{array}$ & $\begin{array}{l}\text { Who Uses the } \\
\text { Information }\end{array}$ & $\begin{array}{l}\text { Relevance to } \\
\text { Future } \\
\text { Performance }\end{array}$ \\
\hline $\begin{array}{l}\text { Customer } \\
\text { Experience } \\
\text { Management } \\
\text { (CEM) }\end{array}$ & $\begin{array}{l}\text { Captures } \\
\text { and } \\
\text { distributes } \\
\text { what a } \\
\text { customer } \\
\text { thinks }\end{array}$ & $\begin{array}{l}\text { At points } \\
\text { of } \\
\text { customer } \\
\text { interaction } \\
\text { 'touch } \\
\text { points' }\end{array}$ & $\begin{array}{l}\text { Surveys, } \\
\text { targeted } \\
\text { studies, } \\
\text { observational } \\
\text { studies, "voice } \\
\text { of customer" } \\
\text { research }\end{array}$ & $\begin{array}{l}\text { Businesses or } \\
\text { functional } \\
\text { leaders, in } \\
\text { order to create } \\
\text { fullfillable } \\
\text { expectations } \\
\text { and better }\end{array}$ & $\begin{array}{l}\text { Leading: } \\
\text { Locates places } \\
\text { to add } \\
\text { offerings in the } \\
\text { gaps between } \\
\text { expectations }\end{array}$ \\
\hline
\end{tabular}




\begin{tabular}{|l|l|l|l|l|l|}
\hline & $\begin{array}{l}\text { about a } \\
\text { company }\end{array}$ & & $\begin{array}{l}\text { experiences } \\
\text { with products } \\
\text { and services }\end{array}$ & $\begin{array}{l}\text { and } \\
\text { experience. }\end{array}$ \\
\hline $\begin{array}{l}\text { Customer } \\
\text { Relationship } \\
\text { Management } \\
\text { (CRM) }\end{array}$ & $\begin{array}{l}\text { Captures } \\
\text { and } \\
\text { distributes } \\
\text { what a } \\
\text { company } \\
\text { knows } \\
\text { about a } \\
\text { customer }\end{array}$ & $\begin{array}{l}\text { After there } \\
\text { is a record } \\
\text { of a } \\
\text { customer } \\
\text { interaction }\end{array}$ & $\begin{array}{l}\text { Point-of-sales } \\
\text { data, market } \\
\text { research, Web } \\
\text { site click- } \\
\text { through, } \\
\text { automated } \\
\text { tracking of } \\
\text { sales }\end{array}$ & $\begin{array}{l}\text { Customer- } \\
\text { facing groups } \\
\text { such as sales, } \\
\text { marketing, } \\
\text { field service, } \\
\text { and customer } \\
\text { service, in } \\
\text { order to drive } \\
\text { more efficient } \\
\text { and effective } \\
\text { execution. }\end{array}$ & $\begin{array}{l}\text { Lagging: } \\
\text { Drives cross } \\
\text { selling by } \\
\text { bundling } \\
\text { products in } \\
\text { demand with } \\
\text { ones that aren't }\end{array}$ \\
\end{tabular}

Moreover, many CEOs don't sufficiently appreciate the distinction between customer satisfaction, which they believe they have heavily documented, and customer experience, which always demands further investigation.

\section{Lack of Attunement to Customers' Needs}

Leaders who rose through customer-facing functions, such as Cisco Systems CEO John Chambers, are more likely to act with reference to customer experience than those who have not. When competing new technologies are difficult to choose among, Cisco defers its choice until key customers have registered their reactions. Because the company knows there will be a market for the choice it finally makes, it can afford to commit itself later than its competitors. In contrast, executives who rose through finance, engineering, or manufacturing often regard managing customer experience as the responsibility of sales, marketing, or customer service.

\section{Fear of What the Data May Reveal}

It's easy to say one's business is customer-driven when there are no data to prove otherwise. Once data start flowing, the bogeymen come out of the closet. Can we afford to do what customers are asking for? How do we choose between conflicting preferences? Can we accept what customers say they are experiencing without first telling them what they should be experiencing? Corporate leaders who would never tolerate a large gap between forecasted and actual revenues prefer to look the other way when company and customer assessments diverge, as they do in the Bain survey.

Executives also hesitate to act on findings because experience data are more ambiguous than customers' actions - the orders they place, for instance. However, statistical analysis has developed to the point where it can dependably quantify both the relative importance of each touch point and the experience it provided. It can also isolate key transactions, accounts, regions, customer segments, and so forth, and then parse the resulting data. About ten years ago, companies started collecting experience information electronically. Now they can instantly combine it with data collected from CRM systems and other customer databases, conduct analyses of both individual and aggregate responses in real time, and then automatically route and track issues needing resolution. 


\section{All Hands on Board}

Many organizations place responsibility for collecting and assessing customer experience data within a single, IT-supported customer-facing group. Doing so accomplishes at least three things: It saves money; it protects customers from redundant and annoying solicitations; and it permits direct comparison of customers on the basis of their location, choice of product, or some other criterion. But it is a mistake to assign to customer-facing groups overall accountability for the design, delivery, and creation of a superior customer experience, thereby excusing those more distant from the customer from understanding it.

In contrast to this common pattern, Palm drew on customer experience to make the Treo one of its most successful products ever. A combination of cell phone and Palm Pilot, the original Treo used the same built-in rechargeable battery as the Palm organizers. When used as a cell phone, the device consumed far more power than it did when used as an organizer. So customers who were heavy users of the cell phone feature found that their Treos were often losing power-and often at an inconvenient distance from their rechargers. Complaints about this problem began showing up in Palm's customer-service transaction surveys. But the customer service department could offer the Treo's unhappy owners only minor power-saving tips. Dissatisfied with the status quo, customer service vice president Dan Gilbert, showing unusual initiative, distributed the experience data his department had collected to product development, which went to work on the problem.

\section{Obtaining the Right Information}

There are three patterns of customer experience information, each with its own pace and level of data collection. (For a detailed breakdown of the three patterns, see the exhibit-2 "Tracking Customer Experience: Persistent, Periodic, Pulsed.")

Exhibit -2 Patterns of Customer Experience Management

\begin{tabular}{|c|c|c|c|c|}
\hline $\begin{array}{l}\text { Pattern and } \\
\text { Purpose }\end{array}$ & Owner & $\begin{array}{c}\text { Data Collection } \\
\text { Frequency and } \\
\text { Scope } \\
\end{array}$ & $\begin{array}{c}\text { Collection and } \\
\text { Analysis } \\
\text { Methodology }\end{array}$ & $\begin{array}{l}\text { Discussion and } \\
\text { Action Forums }\end{array}$ \\
\hline $\begin{array}{l}\text { Past Patterns: } \\
\text { Captures a recent } \\
\text { experience. } \\
\text { Intended to } \\
\text { improve } \\
\text { transactional } \\
\text { experiences } \\
\text { Tracks experience } \\
\text { goals and trends } \\
\text { Assesses impact of } \\
\text { new initiatives } \\
\text { Identifies emerging } \\
\text { issues }\end{array}$ & $\begin{array}{l}\text { Central group } \\
\text { or functions }\end{array}$ & $\begin{array}{l}\text { Persistent: } \\
\text { Electronic } \\
\text { surveys linked to } \\
\text { high-volume } \\
\text { transactions or an } \\
\text { ongoing feedback } \\
\text { system } \\
\text { Automatically } \\
\text { triggered by the } \\
\text { completion of a } \\
\text { transaction } \\
\text { Focused, short- } \\
\text { cycle, timed data } \\
\text { collection } \\
\text { Feedback, } \\
\text { volunteered by }\end{array}$ & $\begin{array}{l}\text { Web based, in- } \\
\text { person, or } \\
\text { phone surveys } \\
\text { User forums } \\
\text { and blogs }\end{array}$ & $\begin{array}{l}\text { Analysed within } \\
\text { functions, } \\
\text { central, survey } \\
\text { groups, or both } \\
\text { Cross- } \\
\text { functional } \\
\text { issues directed } \\
\text { to general } \\
\text { managers } \\
\text { Strategic } \\
\text { analysis and } \\
\text { actions directed } \\
\text { by general } \\
\text { managers }\end{array}$ \\
\hline
\end{tabular}




\begin{tabular}{|c|c|c|c|c|}
\hline & & $\begin{array}{l}\text { users in online } \\
\text { forums }\end{array}$ & & \\
\hline $\begin{array}{l}\text { Present Pattern: } \\
\text { Tracks current } \\
\text { relationships and } \\
\text { experience issues } \\
\text { with an eye toward } \\
\text { identifying future } \\
\text { opportunities. } \\
\text { Keeps a consistent } \\
\text { yet deeper watch } \\
\text { on state of } \\
\text { relationship and } \\
\text { other factors } \\
\text { Looks forward as } \\
\text { well as backward } \\
\text { Used with more } \\
\text { critical populations } \\
\text { and issues } \\
\end{array}$ & $\begin{array}{l}\text { Central } \\
\text { group, } \\
\text { business units } \\
\text { or functions }\end{array}$ & $\begin{array}{l}\text { Periodic: } \\
\text { Quarterly account } \\
\text { reviews } \\
\text { Relationships } \\
\text { studies } \\
\text { User experience } \\
\text { studies } \\
\text { User-group } \\
\text { polling }\end{array}$ & $\begin{array}{l}\text { Web-based } \\
\text { surveys } \\
\text { preceded by } \\
\text { preparation in } \\
\text { person } \\
\text { Direct contact } \\
\text { in person or by } \\
\text { phone } \\
\text { Moderated user } \\
\text { forums } \\
\text { Focus groups } \\
\text { and other } \\
\text { regularly } \\
\text { scheduled } \\
\text { formats }\end{array}$ & $\begin{array}{l}\text { Initial analysis } \\
\text { by sponsoring } \\
\text { group } \\
\text { Broader trends } \\
\text { and issues } \\
\text { forwarded to } \\
\text { general } \\
\text { managers } \\
\text { strategic and } \\
\text { operating } \\
\text { forums } \\
\text { Deeper analysis } \\
\text { of emerging } \\
\text { issues at the } \\
\text { corporate, } \\
\text { business unit, or } \\
\text { local level } \\
\end{array}$ \\
\hline $\begin{array}{l}\text { Potential Patterns: } \\
\text { Targets inquiries } \\
\text { to unveil and test } \\
\text { future } \\
\text { opportunities. }\end{array}$ & $\begin{array}{l}\text { General } \\
\text { management } \\
\text { or functions }\end{array}$ & $\begin{array}{l}\text { Pulsed: } \\
\text { One-off, special } \\
\text { purpose driven } \\
\text { Interim readings } \\
\text { of trends }\end{array}$ & $\begin{array}{l}\text { Driven by } \\
\text { specific } \\
\text { customers or } \\
\text { unique } \\
\text { problems } \\
\text { Very focused } \\
\text { Incorporates } \\
\text { existing } \\
\text { knowledge of } \\
\text { customer } \\
\text { relationship }\end{array}$ & $\begin{array}{l}\text { Centered within } \\
\text { sponsoring } \\
\text { group with } \\
\text { coordination by } \\
\text { and support } \\
\text { from central } \\
\text { group }\end{array}$ \\
\hline
\end{tabular}

Tracking Customer Experience: Persistent, Periodic, Pulsed Companies can monitor various patterns of interaction with customers to gain a better understanding of the customer experience they are providing. Depending on the precise information a company is seeking, it may choose to analyze past patterns, present patterns, potential patterns, or a combination. Each pattern requires a distinct method of generating and analyzing data and will yield different types of insights.

Analyses of present patterns are not simply evaluations of the meaning and success of a recent encounter. They envision a continuing relationship with the customer. Consequently, questions may extend to the customer's awareness of alternative suppliers, new features the customer might desire, and what it sees as challenges to its competitiveness. Given the broad scope of the inquiry, this type of monitoring shouldn't be triggered solely by a customer initiated transaction. Instead, information on a company's key products and services should be gathered at scheduled intervals, or "periodically." Hewlett-Packard and the consulting firm BearingPoint, for example, approach every key customer annually. By initiating contact with different customers at different times throughout the year, BearingPoint has created an almost persistent data flow that does not depend 
on the completion of a given transaction, while permitting comparisons among customers on a range of issues. BearingPoint learned in this fashion that the best practices it had established in one vertical-market group had not migrated to other groups.

Potential patterns are uncovered by probing for opportunities, which often emerge from interpretation of customer data as well as observation of customer behavior. Like the study Gilead conducted, such probes are outgrowths of strategies usually involving the targeting of particular customer segments and are therefore unscheduled, or "pulsed." The findings are often used to inform the product development process.

Most companies apply a single summary metric to data on past and present patterns. The customer experience metric Net Promoter, for example, registers customers' experiences in aggregate - that is, their positive ones minus their negative ones. Intuit's founder, Scott Cook, uses Net Promoter scores for goal setting and engaging the organization's attention, though he recognizes that a rising or falling score doesn't begin to reveal what is driving the trend.

As relationships with customers deepen, companies tend to collect data with greater frequency. The patterns that emerge suggest further areas of inquiry. For example, present relationship studies may indicate that on-site service experience is wanting. After improvements are made, it's common to use a transaction survey following each service call to assess progress. A subsequent, more comprehensive survey may show good experience with service response time but low overall ratings, triggering a special study to identify customers' priorities among a range of service experience factors.

Low cost and ease of modification make surveys the overwhelming favorite for measuring past and present patterns. E-mail-based surveys are superior to paper-based ones because they can be more easily shared; they allow rapid distribution; they give the surveyor the flexibility to extend or abbreviate the questioning according to the wishes of the respondent or the substance of the response; they minimize delays in analyzing the results; and they lead to quick action, such as a referral to a general manager should scores fall below a predetermined level. E-mail surveys can also be more easily tailored.

A well-designed survey is not simply one that elicits the desired information. It must itself avoid becoming an unfortunate aspect of the customer experience. Hence, it shouldn't be onerous for the taker or deny him the chance to communicate the special nature of his experience. One way of keeping surveys mercifully brief is to avoid asking about matters like recent purchases that the company already has a record of. Nor should they be triggered by the transactions of regular customers such as purchasing agents. Such customers are, after all, among those a business can least afford to annoy. By the same token, corporate sanctions imposed on dealers who receive low scores shouldn't be so harsh that retailers try to discourage customers from responding by offering to fix any problem on the spot. The individual customer may be placated, but widespread resort to this practice keeps general management from obtaining a broad picture of systemic problems. 


\section{Customer Experience in Retail Banking}

According to Grewal et al. (2009) customer experience includes every point of contact at which the customer interacts with the business. In retail banking these points of contact are the bank branch, automated teller machines (ATMs), telephone banking, cellphone banking and internet banking. The branch experience, ATMs experience, internet banking experience, telephone banking experience, cellphone banking experience as well as service delivery and service quality - all these shape customer experiences and behaviours.

Backstrom and Johansson (2006) argue that the branch experiences are to a large extent constituted by the behaviour of the bank's staff, service offerings and the layout and design of the facilities. The friendliness of the bank personnel, their competence and knowledge about the products and services offered, as well as a pleasant and welcoming branch environment, can lead to an enhanced customer experience. If the bank employees are polite, responsive and knowledgeable, strong relationships can be formed between the bank and its customers. These relationships tend to lead to satisfied, committed and loyal customers.

The branch layout and design has a significant impact on the customer experience. $\mathrm{Ng}$ (2002) finds that the physical features of the retail outlet such as the layout and background music influence customers' experiences and satisfy their psychological needs for social interaction, comfort and sensory stimulation. The design of the retail bank branch has become critical for the success of the business. Capitalising on the branch design and layout by creating an open and welcoming environment conducive to building customer relationships has become very important.

The advent of internet banking, the proliferation of ATMs and telephone and cellphone banking have provided alternative service distribution channels to the traditional branch banking. These alternative methods of banking offer customers flexibility, convenience and 24 hour access to banking services. The efficiency and seamless delivery of services through these channels impact on the customer experience. According to Calisir and Gumussoy (2008), the development of alternative banking service delivery channels is key to retaining the existing customers as well as attracting new ones.

Banks generate revenues by charging fees for services such as credit, transaction, savings and investment account. The prices and quality of services, distribution technologies and volumes of the customers served are the major elements of competition in the industry. The fees charged by banks influence the consumer's decisions and are the major consideration in the choice of a bank. Van Heerden and van der Westhuizen (2008) find that the retail banking customers have experienced relatively large increases in bank services fees over the last ten years.

Retail banks offer customers a variety of products and services. These offerings can be classified under three primary activities; taking deposits, issuing loans and investing in securities (Kablan, 2009). Due to increased competition among banks and non-bank financial services, these products and services have become commoditised (Devlin \&Gerrard, 2004; Haenlein, Kaplan \&Beeser, 2007). New innovations and products are easy to replicate and differentiating solely on the basis of product offerings and price in the marketplace no longer give competitive advantage. 
The retail banking consumers have evolved; they have become more and more sophisticated and demanding (Arbore \&Busacca, 2009). These consumers demand a wide range of suitable banking products and services. They differ in their sensitivity to price, preference for distribution technology and average distance from the retail bank. The retail banking consumers evaluate financial products on price, convenience and quality (Byers \&Lederer, 2001). Their changing behaviour and attitudes make it easy for them to switch banks if they are dissatisfied. As a result, consumer switching has became a major concern throughout the financial services sector, particularly in the mortgage market (Dougan, 2004). The customer complaints are often accompanied by a rise in the number of those who switch to the other service providers.

\section{The antecedents of customer experience}

The impact of the following antecedents of customer experience in the retail banking environment can be identified.

Social Environment: Research has shown that the consumer's perceptions about the product or service can be influenced by people and groups they associate with White and Dahl (2007) demonstrate that the desire to avoid certain groups of people can influence consumer evaluations and choices. To emphasise the influence of social environment on the consumer's preference and choice, Berger and Heath (2007) argue that people often diverge from their internal drives to ensure that others make desired identity inferences about them. The need to identify with others and conform to their expectations contributes to the consumer's decision-making process within the social setting. Wooten and Reed II (2004) argue that people who value approval but lack confidence in their abilities to discern or enact desired impressions often protect themselves from losses of approval by avoiding undesired, contestable, or even noticeable impressions.

Service Encounter (Interaction): Service encounters involve social interaction between the customer and the service provider. For the service provider, such an encounter represents a moment of truth. According to Czepiel (1990) the success of the business depends on the functional and social performance of the service provider's interactions with the customer.

Over time service encounters can develop into a close social relationship which ultimately can lead to a psychological loyalty between the customer and the service provider. Reynolds and Beatty (1999) examine the nature of a relationship between a consumer and service provider and the role that relationship plays in enhancing the service experience.

Atmosphere: The spending behaviour of the consumer can be significantly influenced by the store atmosphere (Kamaladevi, 2010). Store atmospherics are increasingly considered as a means of creating a pleasurable consumption experience for the consumer. The nicer retail environments and prestigious ambience environment can lead to an increase in the perceived level of credibility towards a service provider and subsequently a higher likelihood to purchase.

Baker, Parasuraman, Grewal and Voss (2002) argue that the store's environmental dimensions (design, social and ambient) influence consumers' perceptions of store choice. These perceptions refer to inferences about the levels of quality, price and the value that consumers would expect in a store on the basis of store environment cues. Bitner (1992) states that the physical setting can be used as a way in which customers can be attracted to and/or satisfied by a firm's services. He 
demonstrates how the physical setting of a service firm can aid or hinder the accomplishment of both internal organisational goals and external marketing goals.

Service Offering: Services are designed to meet the customer's needs by appropriately integrating the company's investments in physical assets, processes, people skills and materials. (Kamaladevi, 2010) defines customer service as the ability of an organisation to constantly and consistently give the customers what they want and need.

Hume et al. (2006) argue that the service experience is created through a series of encounters and interactions between the provider and the consumer, and that the extent to which these encounters are consistent with the customers' wants and needs relate to the value, customer satisfaction and the quality of service.

Price (Cost structure): The consumer's perception of price, quality and value of an offering plays a significant role in influencing shopping behaviour and product choice. Zeithaml (1988), defines price from a consumer's perspective as that which is given up or sacrificed to obtain a product. For the seller, a price captures the value created and earns revenue. According to Grewal et al. (2009), if the price of a product or service is too high, consumers may view it as poor value for money and will not buy. On the other hand, if the price is set too low consumers may perceive the product or service to be of poor quality, standard or other negative attributes and may not buy it either. Rao and Monroe (1989) suggest that for consumer products, there is a significant correlation between price and perceived quality and value of an offering.

Brand: Brands and branding play an important role in the organisation and an increasing number of firms recognise brands as their most valuable assets. According to Kimpakorn and Tocquer (2007) the concept of brand has its roots in the consumer field and is often defined from a customer's perspective. Kimpakorn and Tocquer (2007) define a brand as a collection of associations in the mind of a customer which are connected to a brand or a symbol. The brand equity therefore, is determined by the value, uniqueness and the power of these associations.

Electronic Channels (ATMs, Internet banking etc.): The advances in telecommunication, information technology and the online technology and security have brought about new opportunities and possibilities for both the sellers and buyers of goods and services. Online retailing, as a way of doing business, enables retailers to attract consumers who demand efficient use of their time and are less interested in traditional retailing. From the consumers' perspective, online retailing offers convenience and transcends the limitation of time and space.

Past Customer Experience: The consumer's past experiences and interactions with a retailer or service provider create an image and perceptions which influence consumers' attitudes and behaviour towards the store. According to Osman (2001) the customer's perception and attitude towards the store may be as a result of consumer's evaluation of the perceived important aspects of the store, moulded and remoulded by his/her direct experiences with the store's overall milieu. Woodruff, Cadotte and Jenkins (1983) point out that a consumer's beliefs about the brand are derived from personal use experience and that the nature and amount of a consumer's experience with an evoked set of brands are important determinants of the satisfaction process. 


\section{Conclusion}

Financial services firms across the world are striving to improve their business processes by liaising with customers to survive and compete successfully. In the present day highly competitive environment managing relationship with customer and ensuring customer delight has become a necessity. Customer loyalty is crucial for both organization and customers. Customer experience is the product of an interaction between an organization and a customer over the duration of their relationship. The key elements involved in customer experience management includes - strategy, culture, expectations, processes, marketing and brand, systems and people. The CEM was neglected in the organizations due to - too much money already spent on CRM, lack of attunement to customers' needs, fear of revealing data etc. The customer experience in the retail banking mainly impacted by social environment, service encounter, service offering, brand and past customer experience. Banks willing to improve their relationships with customers need constant monitoring of customer experience. The managers need to exercise some benchmarks which should be used as the basis for comparision with major competitors. The customer knowledge management, satisfaction, trust and loyalty play a key role in the overall process of customer experience management.

\section{References}

[1] Suhail A. Bhat, Mushtaq A Dazari, and Shekir H. Parrey "Antecentents of customer loyalty in Banking sector- A Mediational study" Vikalp: The Journal for Decision Makers, 43 (2) , 2018, 92 105.

[2] Buren, A, Schierholz, R, Kolbe.L.M\& Benner, W "Improving performance of customer processer with knowledge management" Business process Management Journal, 11 (5), 2005, 573-588.

[3] Dahlstrom, R, Nygaard, A., Kimashave, M, \&Ulunes, A.M, "How to recover trust in banking industry? A game theory approach to empirical analysis of bank and corporate customer relationships",International Journal of Bank Marketing, 32(4), 2014, 268-278.

[4] Rangrajan C "The Indian Banking system Challenges ahead" Indian Institute of Banking and Finance, First R.K. Talwar Memorial Lecture, July 31, 2007.

[5] Uppal R.K., "Indian Banking in the Globalised world". New Centry publications, New Delhi, 2008.

[6] Schmittbernt. "Experiential Marketing", Journal of marketing management". Vol.15,1999, PP5367.

[7] Berry, Leorard L, Lewis P, carbone and Stephen H. Hacked.” Managing the customer experience", Sloan Management Review, Vol.43, 2002, PP 85-89.

*Corresponding author.

E-mail address: mbsuvarchala@ gmail.com/profvnrdirectormba@gmail.com 